\title{
Implementation of Government Policy in Guidance Micro, Small and Medium Enterprises in Kabupaten Purwakarta
}

\author{
Agus Kusumaramdhani ${ }^{1}$, Agus Supriyadi ${ }^{2}$, Ahmad Abror ${ }^{3},{ }^{4}$ Atyanto Mahatmyo ${ }^{4}$, \\ Masruchin $^{5}$ \\ guskus@akuntansi.pnj.ac.id ${ }^{1}$, agus.supriyadi@akuntansi.pnj.ac.id², \\ ahmad.abror@akuntansi.pnj.ac.id ${ }^{3}$, atyanto.mahatmyo@akuntansi.pnj.ac.id ${ }^{4}$, \\ masruchin@umsida.ac.id
}

Jurusan Akuntansi Politeknik Negeri Jakarta ${ }^{1,2,3,4}$, Universitas Muhammadiyah Sidoarjo ${ }^{5}$

\begin{abstract}
The existence of MSMEs in Indonesia plays an important role in improving the nation's economy and helping government programs because it is a labor-intensive business that requires a lot of labor. Kabupaten Purwakarta has potential human resources academically, a source of creative and innovative young entrepreneur candidates. But without the maximum support and encouragement from the local government, this will become an obstacle. The purpose of this study is to identify the implementation of policies carried out by the Government of Kabupaten Purwakarta in the development of Micro, Small and Medium Enterprises and describe the driving factors and inhibiting factors faced by the Government of Kabupaten Purwakarta in the implementation of MSME development policies. This research is a descriptive study using a qualitative approach. The research subjects in this study were determined purposively. Data collection techniques are done by interview, observation, and documentation. Source triangulation techniques are used to check the validity of research data. Data analysis in this study uses data collection, data reduction, data display and conclusion making The results of this study indicate that the implementation of development programs for MSMEs.
\end{abstract}

Keywords: MSMEs, Policy Implementation, Development, Local Government

\section{Pendahuluan}

Usaha Mikro, Kecil, dan Menengah atau yang sering disebut UMKM adalah kegiatan yang mempunyai kekuatan untuk mendorong dalam pembangunan ekonomi kemasyarakatan. UMKM akan meningkatkan pertumbuhan ekonomi sebuah negara dan memberikan solusi atas persoalan jobless (pengangguran) dengan membuka lapangan kerja baru. Sektor ini mampu beradaptasi dengan pasang surut permintaan pasar sehingga UMKM bersifat fleksibel. Usaha Mikro, Kecil dan Menengah lebih cepat menciptakan lapangan pekerjaan dibangingkan dengan sektor usaha lainnya, serta cukup terdiversifikasi dalam memberikan pengaruh signifikan terhadap pertumbuhan ekspor dan perdagangan. Oleh karena itu, UMKM adalah salah satu sektor usaha yang menjadi aspek penting untuk pertmbuhan ekonomi yang kompetitif.

Perkembangan industri mikro dan kecil mampu mendukung program Pemerintahan Negara Kesatuan Republik Indonesia dalam meningkatkan pertumbuhan ekonomi serta mengatasi pengurangan tingkat pengangguran dengan menciptakan lapangan kerja baru. Target Pemerintah adalah pada akhir tahun 2020 pencapaian Usaha Mikro, Kecil dan Menengah terhadap peningkatan jumlah ekspor meningkat sebesar 4\%, yaitu dari sebelumnya 14\% menjadi 18\%. Demikian pula dengan pencapaian UMKM (Usaha Mikro, Kecil, dan Menengah) yang memberikan kontribusi Gross Domestik Product (GDP) nasional yang secara otomatis mampu memberikan sumbangan positif menjadi $61 \%$ dengan perbandingan enterpreneurship sebesar 3,55\% [1]. Namun, usaha mikro dan kecil sering mengalami permasalahan salah satu diantaranya adalah kurangnya akses informasi untuk 
mendapatkan kredit/pembiayaan, sehingga hal tersebut dapat mengurangi perkembangan dan pertumbuhan investasi pelaku usaha.

Dasar hukum tentang Usaha Mikro Kecil dan Menengah tertuang dalam Undangundang No. 20 tahun 2008, [2] merupakan dasar hukum Pemerintah Pusat maupun Pemerintah Daerah untuk mendukung kegiatan usaha yang berskala kecil dan menengah dengan kebijakan - kebijakan yang meliputi berbagai aspek. Aspek tersebut meliputi promosi, sarana prasarana, berbagai informasi khususnya informasi usaha, pendanaan, kemitraan, ijin usaha, serta dukungan institusi. Khusus pendanaan, keputusan yang dikeluarkan pemerintah tersebut harus ditujukan untuk memberikan kelonggaran sumber pendanaan dan memberikan fasilitas pada pelaku UMKM terkait kemudahan pembiayaan bank/non bank dengan memberikan fasilitas kemudahan dan adanya jaminan dari pemerintah.

Amanat UU No. 20 tersebut memberikan isyarat kepada pemerintah untuk membantu UMKM dalam mengatasi kurangnya akses pelaku usaha mikro dan kecil untuk memperoleh kredit/pembiayaan dengan peluncuran program yaitu Kredit Usaha Rakyat (KUR) pada tahun 2007. Selama kurun waktu delapan tahun tersebut, yaitu tahun 2007 2014, realisasi penyaluran KUR dapat mencapai target yang ditetapkan pemerintah[3].

Penerapan UU No. 22 tahun 1999 [4] merupakan dasar hukum kemudahan dan kewenangan serta kebebasan Pemerintah Daerah dalam mengurus dan mengatur masyarakat daerahnya masing-masing sesuai dengan aspirasi masyarakatnya. Begitu juga dengan implementasi dari undang-undang ini yang mengatur bagaimana cara pemerintah melakukan pembinaan usaha kecil dan menengah guna mendukung pertumbuhan ekonomi secara nasional. Artinya, upaya pembinaan UMKM merupakan tanggung jawab bersama yaitu, tanggung jawab pemerintah daerah dan juga tanggung jawab pemerintah pusat, dan Kabupaten Purwakarta sebagai bagian dari Pemerintah Daerah juga termasuk di dalamnya.

Dalam penelitian ini akan mengulas peran kebijakan pemerintah dalam pembinaan UMKM agar dalam pelaksanaannya mengalami optimalisasi dan efisiensi dalam program peningkatan dan pemberdayaan UMKM agar lebih maksimal lagi. Variabel kebijakan pemerintah yang dijalankan menjadi penting untuk diketahui dan diimplementasikan agar UMKM yang ada saat ini memiliki daya saing dengan perusahaan lainnya. Seperti kita ketahui bersama bahwa UMKM seringkali mengalami kendala dan kalah dalam bersaing dengan perusahaan lainnya. Untuk itu, penelitian ini memberikan peran dalam kebijakan pemerintah agar berpihak pada penyelesaian masalah yang ada di lapangan dengan memeberikan kontribusi positif dalam mencari kekurangan dan mengatasinya agar UMKM dapat memiliki peran perekonomian memajukan daerah Purwakarta secara khusus dan Indonesia secara umum.

\section{Kajian Pustaka}

Kebijakan publik merupakan pengendalian suatu keputusan yang diambil oleh pemerintah terhadap kepemerintahannya. Dalam penyelenggaraannya, kebijakan publik dan hukum di pemerintah daerah sangat diperlukan. Dalam kebijakan publik, salah satu aspek peraturan tentang hukum adalah aspek legalitas yang menyangkut dengan hukum positif. Atas nama hukum, kekuasaan negara yang sah dapat menetapkan aturan yang implementasinya dapat dipaksakan. Pelaku politik dapat mengambil sebuah kebijakan dan memilih serta menetapkan keputusan dalam rangka kepentingan bersama guna mencapai tujuan tersebut

Kebijakan adalah keputusan yang diusulkan oleh pemerintah, kelompok, atau individu yang mempunyai maksud tertentu di dalam suatu lingkungan dimana terdapat hambatanhambatan dan kesempatan-kesempatan terhadap penerapan usulan kebijaksanaan tersebut [5], sedangkan implementasi adalah penerapan keputusan kebijakan, biasanya dalam bentuk perundang-undangan, dan dapat pula berbentuk keputusan keputusan badan peradilan atau perintah-perintah kepala atau pemimpin. 
Pemerintah adalah suatu pengorganisasian yang mempunyai kekuatan dan mempunyai maksud-maksud bersama dalam hal memberikan keterangan bagi urusan kemasyarakatan [6]. Dalam pengorganisasian kekuatan, pemerintah tidak selalu berhubungan dengan organisasi keuatan angkatan bersenjata. Dari uraian tersebut, dapat disimpulkan bahwa Pengertian Pemerintah adalah organisasi terdiri dari orang-orang yang memiliki kekuasaan atau kekuatan politik, yang kemudian atas kekuasaannya tersebut dapat memerintahkan anggota atau masyarakat yang ada di wilayah kekuasaannya. Merumuskan kebijakan publik adalah suatu pedoman yang berisi norma-norma dan nilainilai yang mempunyai kekuatan untuk mendukung kewenangan pemerintah dalam suatu wilayah yurisdiksinya [7]. Dilain pihak mengatakan bahwa kebijakan publik merupakan cara untuk mencapai tujuan bersama yang dicita-citakan antara masyarakat dan pemerintah [8].

Amanat undang-undang No. 20 tahun 2008 [2], bahwa Usaha Mikro, Kecil, dan Menengah (UMKM) memiliki karakteristik dan pengertian hasil penjualan tahunan yang memenuhi kriteria usaha menengah, yaitu memiliki kekayaan bersih 500 juta rupiah sampai dengan paling banyak 10 milyar rupiah dan tidak termasuk bangunan dan tanah tempat usaha. Sedangkan untuk hasil penjualannya sebesar 2,5 milyar rupiah sampai dengan 50 milyar rupiah.

\section{Metodologi Penelitian}

Sumber data pada penelitian ini adalah data sekunder yang dijadikan sumber data penelitian. Data sekunder adalah merupakan data yang diperoleh dengan mempelajari, membandingkan dan menggabungkan dari berbagai literatur. Data sekunder pada penelitian ini terdiri dari bahan hukum primer, bahan hukum sekunder dan bahan hukum tersier.

Pada penelitian ini, dilakukan prosedur pengumpulan data dengan cara studi literatur. Hal yang dilakukan dalam studi literatur tersebut adalah dengan cara membaca serta melakukan analisis terhadap peraturan perundang-undangan, kebijakan pemerintah baik pusat maupun daerah yang disesuaikan dengan permasalahan serta solusi yang akan dibahas.

Dalam hal pembahasan dan melakukan pengolahan data adalah dengan melakukan klasifikasi data disertai dengan editing data dari data yang telah dikumpulkan. Proses selanjutnya adalah dengan melakukan check and balance terhadap data yang sudah didapatkan.

Kegiatan selanjutnya adalah pertama inventarisasi data, yaitu dengan mengumpulkan dan mencatat segala hal yang berkaitan dengan problematika yang akan dibahas; kedua deskripsi data, yaitu dengan memaparkan dan menggambarkan data secara jelas dan terperinci; ketiga sistematika data, yaitu dengan menyusun data sesuai dengan pokok pembahasan secara terperinci dengan tujuan mempermudah dalam menganalisis; dan yang keempat adalah interpretasi data, yaitu kegiatan yang mengabungkan hasil analisis dari data yang sudah terperinci dengan pernyataan, kriteria, dan standar dalam penelitian yang di bahas.

Penelitian ini dianalisis dengan menggunakan cara analisis deskriptif kualitatif, dengan cara menganalisis setiap kalimat dalam hal menjelaskan data secara jelas, logis, dan terperinci guna mempermudah analisis mengenai permasalahan yang diteliti.Penarikan kesimpulan dilakukan secara induktif dengan melihat fakta secara umum dan memperoleh jawaban dari permasalahan tersebut. 


\section{Pembahasan}

1. Implementasi Kebijakan Pemerintah Daerah Kabupaten Purwakarta dalam Pengembangan UMKM terdiri dari tiga program yaitu

a. Program pengembangan kewirausahaan dan keunggulan kompetitif UMKM Berdasarkan hasil penelitian di Kabupaten Purwakarta, jika dikaitkan dengan Pasal 17 Undang-undang Nomor 20 Tahun 2008, ditemukan fakta bahwa Pemerintah Kabupaten Purwakarta telah berupaya melakukan kegiatan pelatihan manajemen produksi, pelatihan kemasan produk, dan pelatihan manajemen UMKM.

Pelaksanaan pngembangan dalam bidang produksi dan pengolahan sudah maksimal, karena Pemerintah Daerah Kabupaten Purwakarta telah meningkatkan teknik produksi dan memberikan bantuan sarana dan prasarana berupa alat-alat, dan persyaratan Sertifikasi Halal.

Dalam pengembangan sumber daya manusia, Pemerintah Daerah Kabupaten Purwakarta melalui Dinas Perindustrian Koperasi dan UMKM sejak tahun 2012 telah berusaha melakukan mengembangkan sumber daya manusia melalui pelatihan manajemen UMKM, Pelatihan manajemen produk, dan pelatihan kemasan produk. Dalam pelatihan Manajemen UMKM materi di berikan bagaimana cara menjalankan usaha, bagaimana membuat pembukuan usaha dan bagaimana manfaat dari pembukuan. Dalam pelatihan manajemen produk, Pemerintah membantu pelatihan dalam meningkatkan kualitas produk yang lebih bagus lagi dan memenuhi standar maka di ajarkan pelatihan managemen produk ini. Dalam pelatihan kemasan produk di jelaskan cara mengunakan pelabelan pada kemasan, cara menyablon kemasan. Dengan melakukan pelatihan Manajemen produk, Pelatihan kemasan produk, pelatihan manajemen UMKM ini dapat meningkatkan sumber daya manusia.

b. Program pengembangan sistem pendukung usaha bagi Usaha Mikro Kecil dan Menengah UMKM

Berdasarkan hasil penelitian di Kabupaten Purwakarta, jika dikaitkan dengan pasal 8 Undang-undang nomor 20 Tahun 2008 tersebut maka dapat disimpulkan bahwa Pemerintah Daerah Kabupaten Purwakarta melalui Dinas Perindustrian Koperasi dan UMKM memperluas sumber pendanaan dengan bekerjasama dan berkordinasi dengan beberapa lembaga perbankan yaitu Bank Rakyat Indonesia (BRI), dan BJB, dalam memfasilitasi para pengusaha, Pemerintah Daerah Kabupaten Purwakarta.

Jika dikaitkan dengan Pasal 18 Undang-undang Nomor 20 Tahun 2008, ditemukan fakta bahwa Pemerintah Daerah Kabupaten Purwakarta tidak melaksanakan penelitian dan pengkajian pemasaran, akan tetapi Pemerintah Daerah Kabupaten Purwakarta melakukan penyebarluasan informasi pasar melalui kegiatan temu bisnis/usaha dengan Pemerintah Daerah Kabupaten lain dengan tujuan untuk mempromosikan produk unggulanya kepada Daerah lain. Temu bisnis juga sering dilakukan ke pasar-pasar modern untuk mempermudah pemasaran dan mendapatkan konsumen

c. Program penciptaan iklim usaha yang Kondusif

Pemerintah Daerah Kabupaten Purwakarta memberikan kemudahan dalam sarana dan prasarana yang di berikan kepada kelompok UMKM yaitu bantuan alat-alat usaha, antara lain wajan Almunium, las plastik, mesin parut, oven gas 2 buah, serok, solet, baskom, kompor gas tungku, tabung gas, selang regulator, dan lainnya.

Dalam pengembangan desain dan teknologi, Pemerintah Daerah Kabupaten Purwakarta bekerja sama dengan Dinas Koperasi dan UMKM telah meningkatkan kemampuan dalam bidang desain dan teknologi. Hal ini di tujukan dengan pemberian bantuan berupa alat mesin giling bertujuan untuk mempermudah proses penggilingan yang semula masih dengan cara tradisional sekarang bisa dilakukan dengan mesin dan 
dengan adanya bantuan alat ini proses yang semula di lakukan dengan cara sederhana sekarang di lakukan dengan lebih baik.

1. Faktor pendukung implementasi kebijakan pengembangan UMKM

a. Dana

Semua kegiatan yang sudah direncanakan oleh Dinas Perindistrian Koperasi dan UMKM pelaksanaanya disesuaikan dengan besaran APBD Kabupaten Purwakarta

b. Jalinan Kerjasama

Beberapa lembaga yang mendukung program pengembangan UMKM misal Dinas Kesehatan sudah memfasilitasi pembuatan sertifikat Halal dan lembaga pembiayaan modal dalam hal pemberian bantuan kredit untuk perkuatan usaha UMKM sudah berjalan sesusai yang di harapkan

c. Sarana dan Prasarana

Kegiatan pelatihan manajemen produksi Pemerintah Kabupaten Purwakarta sudah memberikan tempat dan konsumsi

2. Faktor penghambat implementasi kebijakan pengembangan UMKM

a. Kurangnya jumlah sumber daya manusia

Dalam menjalankan program-program pengembangan UMKM, Dinas Perindustrian Koperasi dan UMKM masih kekurangan sumber daya manusia, karena banyaknya UMKM yang ada di Kabupaten Purwakarta sedangkan pelaku usaha jumlahnya sedikit. Hal ini dikarenakan banyaknya pemuda yang lebih tertarik bekerja pada perusahaan (pabrik).

b. Banyak produsen yang kesulitan dalam proses pemasaran

Pemerintah Daerah Kabupaten Purwakarta telah memberikan bantuan tentang cara melakukan pemasaran yang baik. Bantuan tersebut misalnya, Pemerintah Daerah Purwakarta memberikan tempat berupa "gallery" yang bertujuan sebagai wadah bagi para pelaku UMKM memamerkan hasil produknya.

c. Belum tersedianya sarana dan prasana yang memadai di sebagian tempat usaha Pemerintah Daerah Kabupaten Purwakarta telah memberikan bantuan sarana dan prasarana tapi jumlahnya yang masih sedikit belum bisa memenuhi kebutuhan sarana dan prasarana yang menyeluruh, sehingga pada sebagian pelaku UMKM masih menggunakan peralatan dan cara tradisional.

\section{Kesimpulan}

Berdasarkan hasil penelitian dan pembahasan maka dapat diambil kesimpulan sebagai berikut:

1. Letak Kabupaten Purwakarta memiliki posisi yang strategis karena merupakan daerah penghubung antara wilayah DKI Jakarta dengan Kota Bandung. Posisi yang strategis ini tentunya memiliki potensi daerah dan peluang yang cukup besar bagi usaha UMKM

2. Implementasi Kebijakan Pemerintah Daerah Kabupaten Purwakarta dalam pengembangan UMKM berjalan dengan baik karena kepentingan angotaangota kelompok sudah terpenuhi, Sesuai Peraturan Daerah Kabupaten Purwakarta Nomor 13 Tahun 2013 Tentang Usaha Mikro Kecil, dan Menengah.

3. Dalam usaha meningkatkan hasil perdagangan UMKM, persoalan yang dihadapi adalah:

a) Masih rendahnya minat para pengusaha dalam menggunakan atau memanfaatkan fasilitas

b) Fasilitas yang diberikan pemerintah belum memberikan kontribusi positif dalam rangka pengembangan industri salah satunya yaitu dengan belum tersedianya infrastruktur kawasan industri yang memadai untuk UMKM. 


\section{References}

[1] http://www.depkop.go.id/read/kemkop-dan-ukm-targetkan-peningkatan-kontribusiumkm-untuk-pdb

[2] Undang-undang No. 20 tahun 2008

[3] http://kur.ekon.go.id/kur-baru-memperluas-akses-pembiayaan-bagi-umkm

[4] Undang-undang No. 22 tahun 1999

[5] Agustino, Leo. 2008. Dasar- dasar Kebijakan Publik. Alfabeta: Bandung

[6] https://www.pelajaran.co.id/2016/05/pengertian-pemerintahan-dan-lembagakekuasaan-pemerintahan.html

[7] Dunn, W.N. (2000). Public Policy Analysis: An introduction, second ed. (terjemahan). Yogyakarta: Penerbit Gadjah Mada University Press

[8] Dwijowijoto, R.N. (2003). Kebijakan Publik: Formulasi, Implementasi dan Evaluasi, Jakarta: PT Elex Media Kumputindo

[9] Supriyadi, Agus. 2015. Framework Ide Bisnis USAha Mikro Kecil dan Menengah (UMKM) Kabupaten Purwakarta. Jurnal Ekonomi \& Bisnis PNJ 